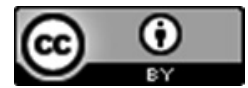

\title{
PHENOLIC CONTENT AND IN VITRO ANTIOXIDANT CAPACITY OF MONO- AND POLYFLORAL HONEYS ORIGINATING FROM SERBIA
}

\author{
Milica T. Atanacković Krstonošić, Jelena M. Cvejić Hogervorst, Veljko S. Krstonošić, Mira P. Mikulić*
}

University of Novi Sad, Faculty of Medicine, Department of Pharmacy, 21000 Novi Sad, Hajduk Veljkova 3, Serbia

${ }^{*}$ Corresponding author

Phone /Fax: +38121422760

E-mail address: mira.bursac@mf.uns.ac.rs

\begin{abstract}
Honey is a natural product of complex composition, recognized for its numerous health benefits. It is believed that honey is especially valuable for prevention of diseases associated with oxidative stress. Antioxidative properties of honeys are mainly attributed to phenolic compounds. The aim of this paper was to determine total phenolic content (TPC) and antioxidant capacity $\left(\right.$ IC $\left._{50}\right)$ in 19 Serbian honeys originating from five different floral sources - three monofloral (acacia, lime, sunflower) and two polyfloral types (meadow and forest). Analyses were performed spectrophotometrically using Folin-Ciocalteu method for total phenolic content determination and $\mathrm{DPPH}^{\circ}$ test for antioxidative capacity. Polyfloral honeys on average had up to two times higher total phenolic content as well as antioxidant capacity than monofloral. The highest phenolic content and antioxidative capacity were observed in forest $(58.35 \mathrm{mg} \mathrm{GAE} / 100 \mathrm{~g})$ and meadow honeys $(0.015$ $\mathrm{g} / \mathrm{mL}$ ), respectively. Acacia honeys distinguished with the lowest values obtained in both tests (17.36 $\mathrm{mg} \mathrm{GAE} / 100 \mathrm{~g} ; 0.067 \mathrm{~g} / \mathrm{mL}$ ). Additionally, significantly high negative correlation coefficient between TPC and $\mathrm{IC}_{50}$ values was noticed in monofloral honeys $(p<0.05)$.
\end{abstract}

Key words: forest honey, meadow honey, acacia honey, lime honey, sunflower honey, total phenolic content

\section{INTRODUCTION}

Honey is a natural product which has been consumed for centuries because of its high nutritive value and recognized health benefits (Alvarez-Suarez et al., 2010a). It is produced by bees (Apis mellifera) from nectar of plants, or from honeydew. Blossom or nectar honey is derived from the nectar of plants while honeydew honey comes from the secretions of living parts of plants or excretions of plant-sucking insects (Pita-Calvo and Vasquez, 2017). Generally, honey presents a complex mixture of over 200 compounds. It consists of carbohydrates $(70-80 \% \mathrm{w} / \mathrm{w})$ - mainly glucose and fructose, water $(10-20 \% \mathrm{w} / \mathrm{w})$ and other minor components such as organic acids, mineral salts, vitamins, proteins, enzymes, phenolic compounds and free amino acids (Ouchemoukh et al., 2007). Honeys can be classified as monofloral or polyfloral. Monoflorals are products of one plant species containing mainly its nectar with minor presence of nectar from other botanical sources. Polyflorals originate from several plant sources, and they can be considered as a blend of few monofloral honeys with significant nectar or honeydew contribution from different plants (Gašić et al., 2014).

Antibacterial, anti-fungal and anti-inflammatory traits of honey are well known and it has been used in traditional medicine even for wound healing (Basualdo et al., 2007). Nowadays, it is recognized that mechanism of anti-inflammatory action is 
complex and could be the result of synergistic effect of different compounds, including phenolics. There are also studies that indicate that honey can help in certain gastrointestinal problems like gastric ulcer and gastritis and exert a hypoglycaemic effect (Erejuwa et al., 2010).

It has been shown that honey, if administered alone or in combination with conventional therapy, has beneficial effect in diseases associated with oxidative stress (Erejuwa et al., 2012). Antioxidant properties of honey are mainly attributed to phenolic compounds which act through stabilization of cell membrane reducing lipid peroxidation. Phenolic compounds are the main plant secondary metabolites. Their content is rather variable and mainly depends on floral source and geographical origin of honey. They can be classified to phenolic acids and their derivates (e.g. syringic, vanillic, coumaric, cinnamic, gallic acid...) and flavonoids (hesperetin, naringenin, luteolin, kaempferol, quercetin...). Other compounds that can express antioxidant activity include certain enzymes (glucose oxidase and catalase), ascorbic acid, proteins and carotenoids (AlvarezSuarez et al., 2010b). Generally, honey is considered as a potential health-promoting food and a rich source of antioxidants with beneficial effects on human health.

Beekeeping and honey production is developing branch of agriculture in Serbia. In order to examine the radical scavenging traits of Serbian honeys, the aim of this paper was to determine total phenolic content and antioxidant capacity in 19 honeys originating from five different floral sources (three monofloral and two polyfloral) produced in two beekeeping regions in Serbia.

\section{MATERIALS AND METHODS}

Honey samples were collected on territory of Republic of Serbia (Vojvodina and Central Serbia) in cooperation with Beekeeper organization of Serbia. They were categorized into five groups according to floral origin - monofloral: group A - acacia honeys with 5 samples (A1-A5); group L lime honeys with 3 samples (L1-L3); group $\mathrm{S}$ - sunflower honeys with 3 samples (S1S3); and polyfloral: group M - meadow ho- neys with 5 samples (M1-M5) and group F - forest honeys with 3 samples (F1-F3). The samples were also observed as monofloral (acacia, lime and sunflower honey) and polyfloral (meadow and forest honey).

All spectrophotometrical measurements were performed on Agilent 8453 UVVisible Spectroscopy System (Germany). For sample preparation Vortex-2 genie (Scientific industries, INC. Bohemia, N.4. 11716, model: G-560 E, USA) was used. Chemicals used were: Folin-Ciocalteu (FC) reagens - Fluka Biochemika (Switzerland); anhydrated sodium carbonate Sinex laboratory (Belgrade); gallic acid monohydrate - Alfa Aesar (Lancaster); 1,1diphenyl-2-pikrylhydrazyl radical (DPPH ${ }^{\circ}$ Sigma Co.-St Louis (USA); ethanol (95-96 vol \%) - ZORKA Pharma a.d. (Šabac).

Honey samples $(1 \mathrm{~g})$ were diluted in distilled water $(10 \mathrm{~mL})$ and stirred on a magnetic stirrer for 20 minutes. The obtained extracts were filtered through a cellulose membrane filter. All measurements were performed in triplicate.

Total phenolics content (TPC) was determined using Folin-Ciocalteu reagent, with modified spectrophotometrical method (Mimica-Dukić et al., 1994) with gallic acid as the standard. Concentrations of total phenolics were expressed as milligram of gallic acid equivalents per $100 \mathrm{~g}$ of honey $(\mathrm{mg}$ $\mathrm{GAE} / 100 \mathrm{~g}$ of honey). Radical scavenging activity was evaluated spectrophotometrically after reaction with 2,2-diphenyl1 picrylhydrazyl (DPPH') free radical (Soler-Rivas et al., 2000). Radical scavenging capacity (RSC) was calculated according to formula: $\% R S C=100-\left(A_{\text {sample }} x\right.$ $\left.100 / A_{\text {blank }}\right)$. Data were presented as inhibitory concentration ( $\mathrm{IC}_{50}$ value $)$ - concentration of sample in $\mathrm{g} / \mathrm{mL}$ necessary for inhibition of $50 \%$ of DPPH radical.

Obtained data were analyzed using MS Excel and Origin 8.1. programs. The differences were considered significant at level 0.05 .

\section{RESULTS AND DISSCUSION}

Obtained values for TPC in monofloral and polyfloral honeys varied from 13.39 to 29.07 and from 23.95 to $83.09 \mathrm{mg}$ GAE/100 g, respectively (Table 1). Ave- 
rage phenolic content of monofloral honeys (lime, sunflower and acacia) was $21.96 \mathrm{mg}$ GAE/100 $\mathrm{g}$ while for polyfloral (meadow and forest) this value was 44.84 $\mathrm{mg}$ GAE /100 g. Polyfloral honeys also had two times higher antioxidant activity (average $I_{50}$ value was $0.021 \mathrm{~g} / \mathrm{mL}$ ), comparing to monofloral samples with average $I_{50}$ of $0.044 \mathrm{~g} / \mathrm{mL}$. Average TPC values obtained for polyfloral samples were 36.74 for meadow, and $58.35 \mathrm{mg}$ GAE/100 $\mathrm{g}$ for forest honeys (Figure 1).

Previously obtained results for total phenolic content of polyfloral Serbian honeys were 3-139 mg GAE/100 g (Gašić et al., 2014), $38.5 \mathrm{mg}$ GAE/100 g (Vulić et al., 2015) and $19.78 \mathrm{mg}$ GAE /100 g (Čanadanović Brunet et al., 2014) which is in accordance with the results from this study.

Similar TPC values for polyfloral honeys produced in Europe were noticed. Wilczynska (2010) reported phenolic content from 37.05 to $53.05 \mathrm{mg} \mathrm{GAE} / 100 \mathrm{~g}$ in 7 polyfloral honeys from Poland. Total phe- nolic contents in 7 polyfloral Croatian honeys were in the range of $20.20-90.75 \mathrm{mg}$ GAE/100 g (Piljac-Žegarac et al., 2009) while TPCs in 7 multifloral honeys from Romania were from 23-125 mg GAE /100 g (Al et al., 2009). Still, lower values have also been observed for Slovenian polyfloral honeys (multifloral 12.68-18.46, forest 19.23-27.05 mg GAE /100 g) (Bertoncelj et al., 2007). The TPC values obtained in our polyfloral samples were also similar with those obtained from others parts of the world. Some of the reported values include polyfloral honeys from Turkey (average $29.54 \mathrm{mg} \mathrm{GAE} / 100 \mathrm{~g}$ ) (Can et al., 2015). The same trend was noticed for multifloral honeys from Burkina Faso with TPC values from 32.6 to $93.7 \mathrm{mg}$ GAE/100 g (Meda et al., 2005). On the other hand, Sanchez et al. (2012) obtained higher values of TPC for multifloral Chilean honeys (58-119 mg GAE/100 g). In general, polyfloral honeys (forest and meadow) had higher phenolic content than monofloral (acacia, lime, sunflower) (Figure 1).

Table 1.

Antioxidant capacity $\left(\mathrm{IC}_{50}\right)$ and total phenolic content (TPC) of honey samples (mean $\left.\pm S D\right)$

\begin{tabular}{|c|c|c|c|}
\hline Sample* & Location & $\begin{array}{c}I C_{50} \\
(g / m L)\end{array}$ & $\begin{array}{c}\text { TPC } \\
(\mathrm{mg} \mathrm{GAE} / 100 \mathrm{~g})\end{array}$ \\
\hline \multicolumn{4}{|l|}{$\begin{array}{l}\text { Monofloral honeys } \\
\text { Acacia }\end{array}$} \\
\hline $\mathrm{A} 1$ & Užice & $0.120 \pm 0.007$ & $13.39 \pm 0.42$ \\
\hline $\mathrm{A} 2$ & Lazarevac & $0.074 \pm 0.003$ & $14.19 \pm 0.25$ \\
\hline A3 & Aleksinac, Jastrebac & $0.080 \pm 0.006$ & $17.61 \pm 0.74$ \\
\hline A4 & Vršac & $0.035 \pm 0.003$ & $18.04 \pm 0.58$ \\
\hline A5 & Sremski Karlovci & $0.027 \pm 0.004$ & $23.59 \pm 0.46$ \\
\hline \multicolumn{4}{|l|}{ Lime } \\
\hline L1 & Novi Sad, Popovica & $0.028 \pm 0.001$ & $22.30 \pm 0.68$ \\
\hline L2 & Sremski Karlovci & $0.028 \pm 0.006$ & $26.32 \pm 0.92$ \\
\hline L3 & Erdevik, Ljuba & $0.025 \pm 0.005$ & $28.13 \pm 0.63$ \\
\hline \multicolumn{4}{|l|}{ Sunflower } \\
\hline $\mathrm{S} 1$ & Plandište, Vršac & $0.023 \pm 0.004$ & $29.70 \pm 1.02$ \\
\hline S2 & Sombor & $0.018 \pm 0.003$ & $22.34 \pm 0.78$ \\
\hline S3 & Kikinda & $0.024 \pm 0.005$ & $25.98 \pm 0.95$ \\
\hline \multicolumn{4}{|l|}{$\begin{array}{l}\text { Polyfloral honeys } \\
\text { Meadow }\end{array}$} \\
\hline M1 & Jasenovo & $0.016 \pm 0.002$ & $38.04 \pm 1.11$ \\
\hline M2 & Lazarevac & $0.015 \pm 0.002$ & $33.06 \pm 0.93$ \\
\hline M3 & Aleksinac, Jastrebac & $0.004 \pm 0.000$ & $50.90 \pm 0.85$ \\
\hline M4 & Gornji Milanovac & $0.024 \pm 0.003$ & $23.94 \pm 1.26$ \\
\hline M5 & Veternik & $0.014 \pm 0.001$ & $37.75 \pm 0.85$ \\
\hline \multicolumn{4}{|l|}{ Forest } \\
\hline $\mathrm{F} 1$ & Fruška gora & $0.023 \pm 0.004$ & $83.09 \pm 1.45$ \\
\hline $\mathrm{F} 2$ & Maja honey, Šimanovci & $0.030 \pm 0.009$ & $67.98 \pm 0.92$ \\
\hline F3 & Timo honey, Knjaževac & $0.045 \pm 0.008$ & $23.98 \pm 1.05$ \\
\hline
\end{tabular}

*A-acacia; L-lime; S-sunflower; M-meadow; F-forest 


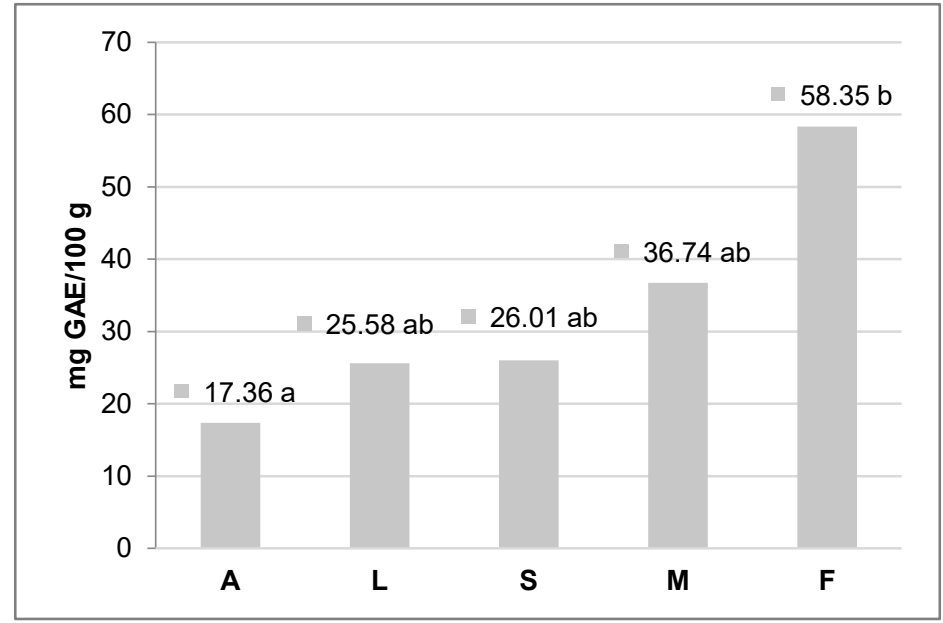

${ }^{a b}$ Different letters show significant statistical difference at level 0.05 *A-acacia; L-lime; S-sunflower; M-meadow; F-forest

Figure 1. Average total phenolic content of different honey types

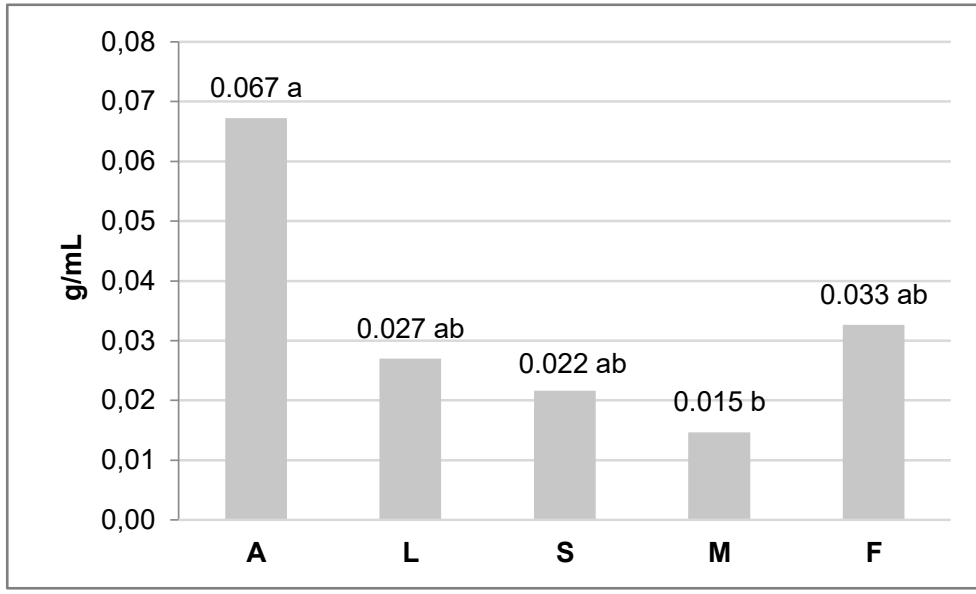

${ }^{a b}$ Different letters show significant statistical difference at level 0.05 *A-acacia; L-lime; S-sunflower; M-meadow; F-forest

Figure 2. Antioxidant activity of different honey types

The highest phenolic content was observed in forest honeys $(58.35 \mathrm{mg}$ GAE/100 g), while the lowest was in acacia (17.36 mg GAE/100 g) which was presented in Figure 1. Statistical ANOVA analysis of TPC data showed that samples did not differ based on botanical origin. The only significant difference $(p<0.05)$ was noticed between acacia and forest samples (Figure 1). These two honey types were also the brightest (acacia honeys) and the darkest (forest honeys) samples. A Slovenian study confirmed that forest honeys (fir, forest and chestnut honeys) are usually dark-colored, while acacia is a light-colored honey (Bertoncelj et al., 2007).

It has been shown that these dark colored honeys have more phenolic compounds compared to light colored (acacia, rape, itd) (Wilczynska, 2010; Bueno-Costa et al., 2016). This is in accordance with our results, although it should be emphasized that chromatic properties of samples were not determined in this study. Previously, it was also reported that dark-colored honey samples have high level of pigments, pollen, phenolic compounds and minerals (Bertoncelj et al., 2007). Pontis et al. (2014) showed that darker honey samples had higher amounts of phenolics, flavones, and flavonols and increased antioxidant 
activity, while the correlation between TPC and honey color was the highest from all tested parameters.

Average TPC values of monofloral honeys were around $26 \mathrm{mg} \mathrm{GAE} / 100 \mathrm{~g}$ for lime and sunflower, while acacia honeys had lower phenolic content (Figure 1). Data reported in literature for Serbian monofloral honeys are 23.96-27.44 for lime, and 16.18-20.04 $\mathrm{mg}$ GAE/100 $\mathrm{g}$ for acacia honeys (Vulić et al., 2015; Čanadanović-Brunet et al., 2014; Savatović et al., 2011). These values are similar to those obtained for lime and acacia honeys from this study. Reported values for lime honey from Poland include 19.25 (Kus et al., 2014) up to $47.14 \mathrm{mg}$ GAE/100 g (Wilczynska, 2010). Polish acacia honey contained $14.2 \mathrm{mg}$ GAE/100 $\mathrm{g}$ which is also comparable to our findings. A study performed on acacia, sunflower and lime honeys from Romania showed TPC values similar to those obtained for our samples of same floral origin (Al et al., 2009). On the other hand, Bertoncelj et al. (2007) noticed lower values of phenolic content in honeys from Slovenia (acacia 2.57-6.79, lime 9-15.9 mg GAE/100 g).

The radical scavenging activity of individual honey samples varied between $0.004-0.12 \mathrm{~g} / \mathrm{mL}$ (Table 1). The highest average antioxidative potential was observed in polyfloral meadow honeys $(0.015$ $\mathrm{g} / \mathrm{mL}$ ), while the lowest was in monofloral acacia $(0.067 \mathrm{~g} / \mathrm{mL}$ ) (Figure 2). ANOVA test analysis of antioxidant activity showed that samples are not grouped according to floral origin. The only statistically significant difference $(p<0.05)$ was noticed between $\mathrm{IC}_{50}$ values of acacia and meadow samples (Figure 2). It is difficult to directly compare these results with other literature data, because of the differences in data presentation. Still, some similar trends in samples from the region can be observed. Vulić et al. (2015) tested lime, acacia and polyfloral honeys, and polyfloral had by far the highest antioxidant potential, while the lowest was in acacia honeys. On the other hand, Savatović et al. (2011) showed that lime honey had the highest antioxidant activity compared to acacia and multifloral honey. Analysis of honeys with four different antioxidant tests showed that polyfloral forest sample exhibited the highest antioxidant capacity while the lowest was in the acacia sample. Experiment performed on Turkish honeys confirmed the lowest average antioxidant activity of acacia honeys, while multifloral and lime honeys had similar antioxidant potential (Can et al., 2015). Czech mea-dow samples had lower antioxidant activity than forest (Lachman et al., 2010), which was not the case in our study.

Correlation between antioxidant activity and total phenolic content for all individual samples did not show statistical signifycance $(R=-0.45 ; p=0.054)$. Similar trend was observed in publication concerning Brazilian honeys which also established that there was no correlation between total phenolic content and antioxidant activity determined by DPPH $^{\circ}$ test. More specifically, this study showed that there was positive correlation between TPC and activity obtained using $\mathrm{ABTS}^{\circ}$ test. Even though it was also not significant, it is considered as an important result (Bueno Costa et al., 2016).

On the other hand, in monofloral honeys significant high negative correlation coefficient between TPC and $I_{50}$ values was noticed $(R=-0.82 ; p=0.002)$. Study preformed on Cuban monofloral honeys also demonstrated significant correlations between TPC values and antioxidant activity (Alvarez-Suarez et al., 2010a). Gorjanović et al. (2013) obtained significant correlations between total phenolic content and antioxidant activity of honeys assessed with four different tests. Results of Kus et al. (2014) also demonstrated that there were significant correlations between TPC and antioxidant activity assessed with FRAP and DPPH test. Analysis of few Serbian honeys also showed that there is high correlation between TPC and antioxidant potential determined with $\mathrm{DPPH}^{\circ}$ (Savatović et al., 2011).

Additionally, no statistically significant correlation was established between TPC and antioxidant capacity of polyfloral honeys $(R=-0.12 ; p=0.77)$, which could imply that other compounds beside polyphenols contribute to their antioxidant activity. Since honey is a very complex natural mixture with various factors that influence its com- 
position it is challenging task to elucidate the role of certain non-phenolic compounds on antioxidant potential. It is also indicated that although phenolic compounds have significant antioxidant potential, there may be synergistic or antagonistic effects between phenolic and nonphenolic compounds (Savatović et al., 2011). The other constituents such as ascorbic acid, $\alpha$-tocopherol, carotenoids could possibly contribute to the total antioxidant activity. Also, importance of antioxidant capacity of some free amino acids and their correlation with radical scavenging activity of honey was pointed out (Meda et al., 2005).

\section{CONCLUSIONS}

Performed study on honeys from different locations in Serbia showed that polyfloral samples on average had up to two times higher total phenolic content as well as antioxidant capacity than monoflorals. The highest phenolic content and antioxidative capacity was observed in forest and meadow honeys, respectively. These values were the lowest in monofloral acacia honeys, which statistically differed only from the highest results obtained for polyfloral samples in both tests. Generally, ANOVA test analysis of TPC and antioxidant activity showed that samples did not group according to floral origin. In monofloral honeys significant high negative correlation coefficient between TPC and $I_{50}$ values was noticed. However, further studies of the individual phenolics in Serbian honeys are needed in order to get better insight into composition of these important health beneficial compounds.

\section{REFERENCES}

1. Al, M.L., Daniel, D., Moise, A., Bobis, O., Laslo, L., Bogdanov, S. (2009). Physico-chemical and bioactive properties of different floral origin honeys from Romania. Food Chemistry, 112, 863-867.

2. Alvarez-Suarez, J.M., Tulipani, S., Diaz, D., Estevez, Y., Romandini, S., Giampieri, F., Damiani, E., Astolfi, P., Bompadre, S., Battino, M. (2010a). Antioxidant and antimicrobial capacity of several monofloral Cuban honeys and their correlation with color, polyphenol content and other chemical compounds. Food and Chemical Toxicology, 48, 2490-2499.

3. Alvarez-Suarez, J.M., Tulipani, S., Romandini, S., Bertoli, E., Battino, M. (2010b). Contribution of honey in nutrition and human health: a review. Mediterranean Journal of Nutrition and Metabolism, 3, 15-23.

4. Basualdo, C., Sgroy, V., Finola, M.S., Marioli, J.M. (2007). Comparison of the antibacterial activity of honey from different provenance against bacteria usually isolated from skin wounds. Veterinary Microbiology, 124, 375-381.

5. Bertoncelj, J., Doberšek, U., Jamnik, M., Golob, T. (2007). Evaluation of the phenolic content, antioxidant activity and colour of Slovenian honey. Food Chemistry, 105, 822-828.

6. Bueno-Costa, F.M., Zambiazi, R.C., Bohmer, B.W., Chaves, F.C., da Silva, W.P., Zanusso, J.T., Dutra, I. (2016). Antibacterial and antioxidant activity of honeys from the state of Rio Grande do Sul, Brazil. LWT - Food Science and Technology, 65, 333-340.

7. Can, Z., Yildiz, O., Sahin, H., Turumtay, E.A., Silici, S., Kolayli, S. (2015). An investigation of Turkish honeys: Their physico-chemical properties, antioxidant capacities and phenolic profiles. Food Chemistry, 180, 133-141.

8. Čanadanović Brunet, J., Ćetković, G., Tumbas Šaponjac, V., Stajčić, S., Vulić, J., Đilas, S., Štajner, D., Popović, B. (2014). Evaluation of phenolic content, antioxidant activity and sensory characteristics of Serbian honey-based product. Industrial Crops and Products, 62, 1-7.

9. Erejuwa, O.O., Gurtu, S., Sulaiman, S.A., Ab Wahab, M.S., Sirajudeen, K.N., Salleh, M.S. (2010). Hypoglycemic and antioxidant effects of honey supplementation in streptozotocininduced diabetic rats. International Journal for Vitamine and Nutrition Research, 80, 74-82.

10. Erejuwa, O.O., Sulaiman, S.A., Ab Wahab, M.S. (2012). Honey: A novel antioxidant. Molecules, 17, 4400-4423.

11. Gašić, U., Kečkeš, S., Dabić, D., Trifković, J., Milojković Opsenica, D., Natić, M., Tešić, Ž. (2014). Phenolic profile and antioxidant activity of Serbian polyfloral honeys. Food Chemistry, 145, 599-607.

12. Gorjanović, S.Z., Alvarez-Suarez, J.M., Novaković, M.M., Pastor, F.T., Pezo, L., Battino, M., Sužnjević, D.Z. (2013). Comparative analysis of antioxidant activity of honey of different floral sources using recently developed polarographic and various spectrophotometric assays. Journal of Food Composition and Analysis, 30, 13-18.

13. Kus, P.M., Congiu, F., Teper, D., Sroka, Z., Jerković, I., Tuberoso, C.I.G. (2014). Antioxidant activity, color characteristics, total phenol content and general HPLC fingerprints of six Polish unifloral honey types. LWT - Food Science and Technology, 55, 124-130.

14. Lachman, J., Orsak, M., Hejtmankova, A., Kovarova, E. (2010). Evaluation of antioxidant activity and total phenolics of selected Czech honeys. LWT-Food Science and Technology, 43, 52-58.

15. Meda, A., Lamien, C.E., Romito, M., Millogo, J., Nacoulma, O.G. (2005). Determination of the total phenolic, flavonoid and proline contents in 
Burkina Fasan honey, as well as their radical scavenging activity. Food Chemistry, 91, 571577.

16. Mimica Dukić, N., Budimčević, M.M., Mihajlović, A.B., Gašić, S.O. (1994). Antioxidant activity of plant phenolics. Flavonoids and phenolic acids. Journal of the Serbian Chemical Society, 59, 823-828.

17. Ouchemoukh, S., Louaileche, H., Schweitzer, P. (2007). Physicochemical characteristics and pollen spectrum of some Algerian honeys. Food Control, 18, 52-58.

18. Piljac Žegarac, J., Stipčević, T., Belščak, A. (2009). Antioxidant properties and phenolic content of different floral origin honeys. Journal of ApiProduct and ApiMedical Science, 1, 4350.

19. Pita-Calvo, C., Vazquez, M. (2017). Differences between honeydew and blossom honeys: A review. Trends in Food Science and Technology, 59, 79-87.

20. Pontis J.A., da Costa L.A. M.A., da Silva S.J. R., FlachA. (2014). Color, phenolic and flavonoid content, and antioxidant activity of honey from Roraima, Brazil. Food Science and Technology, Campinas, 34, 69-73.
21. Sánchez, E., Piovano, M., Valdés, E., Young,

22. M.E., Acevedo, C.A., Osorio, M. (2012). Determination of antioxidant properties of 26 Chilean honeys and a mathematical association study with their volatile profile. Natural Product Communications, 7, 1-4.

23. Savatović, S.M., Dimitrijević, D.J., Đilas, S.M., Čanadanović-Brunet, J.M., Ćetković, G.S., Tumbas, V.T., Štajner, D. I. (2011). Antioxidant activity of three different Serbian floral honeys. Acta Periodica Technologica, 42, 145-155.

24. Soler-Rivas, C., Espin, J.C., Wichers, H.J. (2000). An easy and fast test to compare total free radical scavenger capacity of foodstuffs. Phytochemical Analysis, 11, 330-338.

25. Vulić, J., Čanadanović-Brunet, J., Ćetković, G., Đilas, S., Tumbas Šaponjac, V., Stajčić, S. (2015). Polyfloral, linden and acacia honeys with dried cherries after three months of storage - antioxidant and sensory evaluation. Acta Periodica Technologica, 46, 103-114.

26. Wilczyńska, A. (2010). Phenolic content and antioxidant activity of different types of Polish honey - a short report. Polish Journal of Food Nutrition and Sciences, 60, 309-313.

\title{
САДРЖАЈ ФЕНОЛА И IN VITRO АНТИОКСИДАТИВНИ КАПАЦИТЕТ МОНО- И ПОЛИФЛОРАЛНИХ УЗОРАКА МЕДА СА ТЕРИТОРИЈЕ СРБИЈЕ
}

\author{
Милица Т. Атанацковић Крстоношић, Јелена М. Цвејић Хогерворст, Вељко С. Крстоношић, \\ Мира П. Микулић*
}

Универзитет у Новом Саду, Медицински фракултет, Катедра за фрармацију, 21000 Нови Сад, Хајдук Вељкова 3, Србија

Сажетак: Мед је природни производ сложеног састава, познат по својим благотворним дејствима на људско здравље. Сматра се да има значајну улогу у превенцији обољења повезаних са оксидативним стресом. Антиоксидативна својства меда се у великој мери приписују фенолним компонентама. Циљ овог рада је одређивање садржаја укупних фенола (TPC) и антиоксидативног капацитета $\left(\mathrm{IC}_{50}\right)$ у 19 узорака меда са територије Србије који потичу из пет флоралних извора - три монофлорална (багремов, липов, сунцокретов) и два полифлорална (ливадски, шумски). Анализа је вршена спектрофотометријски применом FolinCiocalteu методе за одређивање укупних фенола и DPPH' теста за одређивање антиоксидативног капацитета. Полифлорални узорци имали су у просеку до два пута већи садржај укупних фенола као и антиоксидативни капацитет у односу на монофрлоралне. Највећи садржај укупних феенола и највећа антиоксидативна активност забележене су код шумског $(58,35 \mathrm{mg}$ $\mathrm{GAE} / 100 \mathrm{~g})$ и ливадског $(0,015 \mathrm{~g} / \mathrm{mL})$ меда, редом. Узорци багремовог меда издвојили су се по најнижим вредностима испитиваних параметара у оба теста (TPC $17,36 \mathrm{mg} \mathrm{GAE} / 100 \mathrm{~g}$; IC 50 $0,067 \mathrm{~g} / \mathrm{ml}$ ). Додатно, установљена је значајна негативна корелација између TPC и $\mathrm{IC}_{50}$ вредности код монофлоралних узорака меда $(p<0,05)$.

Кључне речи: шумски мед, ливадски мед, багремов мед, липов мед, сунцокретов мед, садржај укупних френола

Received: 19 February 2019

Received in revised form: 25 March 2019

Accepted: 5 April 2019 